\title{
District Land Office Purworejo Role in Efforts To Solve Grants Dispute (Case 32 / Pdt.G / 2018 / PN. Pwr)
}

\author{
Bayun Kismantoro ${ }^{1}$ and Akhmad Khisni ${ }^{2}$
}

Abstract. The number of disputes in Purworejo regency, especially in the area of land would make the authors interested in examining disputes and conduct research on the consideration of the judges through decisions that have been stated. Land disputes, is anything that causes disagreements, discord or strife. Dispute is a continuation of the conflict, and the conflict itself is a dispute between two parties, but the dispute was only buried and can not be shown and when the dispute was notified to the other party will be disputed. The problems of this study are 1) How Purworejo District Land Office Role In Resolving Grants Disputes Efforts In Case No.32 / Pdt.G / 2018 / PN.Pwr, 2) How Consideration Judge In Case No.32 / Pdt.G / 2018 / PN.Pwr About Grant Dispute.

This research used normative juridical approach (normative legal research) so called because this research is the study of literature. This study uses a basic decision No.32 / Pdt.G / 2018 / PN.Pwr. Normative research that discusses the doctrines or principles in jurisprudence. The results of this study show that, 1) Role of the District Land Office Purworejo In Effort Resolving Disputes Grant In Case No.32 / Pdt.G / 2018 / PN.Pwr rolegive evidence in the trial to support the strong evidence. 2) Consideration Judge In Case No.32 / Pdt.G / 2018 / PN.Pwr About Grant Dispute. Judge offers mediation in accordance initial steps of the Supreme Court Regulation No. 1 of 2016.

Based on the results of data analysis concluded that give evidence in the trial to support the strong evidence in case of Grant Disputes from the District Land Office Purworejo, consideration of the judge that the plaintiff has successfully refute the arguments of gugatanya partly in what he demanded from the gugatanya. Then the judges verdict. Suggestions for Purworejo Land Office Hopes to be more careful in the process of registration certificates andSense of justice is extremely important for the judge to impose any decision.

Keywords: Land Office; Legal Dispute; Grant.

\section{Introduction}

Dispute is anything that causes disagreements, discord or strife. Dispute is a continuation of the conflict, and the conflict itself is a dispute between two parties, but the dispute was only buried and can not be shown and when the dispute was notified to the other party will be disputed ${ }^{3}$, The next issue is concerned with the grant. The Meaning of the grant itself comes from Arabic language which etymologically means skip over or channel and can also be interpreted to give. Grant is an example of tabbaru agreement that the contract is not intended for profit alone (non-profit), but addressed to someone else for free of charge. In terms of grants is a voluntary provision without hope the contra of the recipient and the gift giving took place during the grantor is still alive. This is distinguishing grant with a will.

In respect of the number of cases that occurred in Indonesia grants, Writers get one of the cases occurred in a region. The area is in Puworejo, precisely in Gebang District of

\footnotetext{
${ }^{1}$ Students Master of Notary, UNISSULA, e-mail: kismantoropambayun@icloud.com

2 Faculty of Law Universitas Islam Sultan Agung

${ }^{3}$ Rachmadi Usman, 2009, Hukum Agraria, Jakarta : Sinar Grafika p. 1
} 
Purworejo. Purworejo is a district that is precisely located in the province of Central Java. The following cases have been thereOne of the grants also disputes that occur in Purworejo. It is described as follows Gebang subdistrict Grant Dispute a suit against the law in the name of the daughter TUKINI binti SONTO MARSONO as PLAINTIFF. Who filed suit on behalf of the law against NANIK ENDANG WATI Binti ONGGO KUMORO as DEFENDANT. So the title of this thesis caused lift want to know the role of Purworejo District Land Office in an effort to resolve the Grant Disputes and knowing considerations judge in an effort to resolve the Grant Disputes In Case No.32 / Pdt.G / 2018 / PN.Pwr

\section{Research methods}

Approach This research used normative juridical approach (normative legal research) is called so because this research is research literature or studies document is done or directed only at the written regulations or other legal materials. ${ }^{4}$

Normative approach is an approach that examines the law as a rule are considered in accordance with normative juridical research or research studies written law or legal research doctrinal, which is working to find answers that are correct by validating sought from the descriptions of the law that is written in the book legislation or books. With a brief that discusses the research normative doctrines or principles in jurisprudence. ${ }^{5}$

This research was conducted by using the approach of studying law as a rule, by validating written on a.) The Constitution of the Republic of Indonesia of 1945, b.) Act No. 5 of 1960 on Basic Regulation of Agrarian (BAL) and c.) Regulation of the National Land Agency of the Republic of Indonesia No. 4 of 2006.

\section{Results And Discussion}

\subsection{The role of Purworejo District Land Office In Effort Resolving Grants Disputes in case No. 32 / Pdt.G / 2018 / PN. Pwr.}

In accordance Indonesian Presidential Regulation No. 30 Of 2015 concerning the National Land Agency has the task in the area of land in accordance with the Laws Invitation, in this case the task of the National Land Agency which has the role of preparation and adoption of policies in the field of land and other tasks are the formulation and implementation of policies in the field of surveying, measuring and mapping the location, the formulation and implementation of policies in the field of the determination of land rights and community empowerment and the formulation and implementation of policies in the field of management control in the case of land disputes.

In a related subject in Purworejo District Land Office's role in efforts to resolve disputes in the case of grants 32 / Pdt.G / 2018 / PN.Pwr the authors refer to the District Court Puworejo and subject the authors analyze the role of the Land Office in

\footnotetext{
${ }^{4}$ Bambang Waluyo, 1996, Metode Penelitian Hukum, Jakarta : Sinar Grafika, p. 13

${ }^{5}$ H. Zainuddin Ali, 2011, Metode Penelitian Hukum, Jakarta : Sinar Grafika, p. 25
} 
an effort to resolve the Grant Dispute in the case Tukini Binti Sonto Marsono as plaintiff against Nanik Endang Wati Binti Onggo Kumoro as Defendant, the Land Office in the exception in the early stages provide answers flatly refused posita lawsuit number 18 which stated "that because there are differences in the boundaries of the object of dispute the on SHM $621 \mathrm{~m}^{2}$ area in 2636 in the name of ending Nanik Endang Wati with conversion parcels former as Yasan rights $1752 \mathrm{C}$ on behalf Dulmanan, then head of the National Agency of BPN should revoke all published evidence on behalf of the defendant from the register recording the rights provided for it " that in the posita not give a reason if SHM $6212623 \mathrm{~m}^{2}$ area is a different ground objects with parcels of land Yasan rights c 1752 then co-defendant II do not need to unplug or certificate cancel comprehensive SHM $2623621 \mathrm{~m}^{2}$. Land Office strongly rejected the plaintiffs' arguments and establishment in lawsuit letter dated August 2, 2018, except as expressly recognized. Land Office also states the proposition that has been delivered in the exception being entered into a fundamental unity in this case. So in the trial role Purworejo District Land Office provide an explanation or evidence to a panel of judges who had been appointed that the publishing process SHM No. $621 \mathrm{~m}^{2}$ area in 2623 in the name of Nanik Endang Wati is flawed.

As well as the District Land Office Purworejo give evidence in the trial to support the strong evidence in case of dispute between Tukini Bint Grant Sonto Marsono as the plaintiff and Nanik Endang Wati Binti Onggo Kumoro as defendant, that filed the following evidence:

- Copy the appropriate native land book 621 of the National Land Agency, given the evidence of TTII-1;

- Copy of the original suit, Grant Deed No. 44 / PPAT / Gebang / 1990, marked as evidence TTII-2;

- Examination of Local Case Number. 32 / Pdt.G / 2018 / PN.Pwr form Parcel Map location is located in the village of Seren, District Gebang, Purworejo, Central Java Province.

In the explanatory that the registration process transfer of rights on the certificate 621 / Seren has been done according to the procedures in force stipulated in Presidential Regulation No.20 of 2015 on National Land Agency as a vertical institution in charge of serving the public interest in the land sector, especially with regard with registration / recording.

So the role of the District Land Office Purworejo in an effort to resolve the Grant Disputes already explained in the case of the above authors analyzed the relation with the Theory of Settlement is a theory that examines and analyzes about the category or classification disputes or conflicts that arise in society, causes of the dispute and how or strategies used to put an end to the dispute ${ }^{6}$. This theory was developed and presented by Ralf Dahrendorf, Dean G Pruitt, Jefrey Z.Rubin. The scope of this theory is the theory of resolving disputes includes types of disputes, factors causing disputes and strategies in the settlement of disputes. So the authors

\footnotetext{
6 Priatna Abdurasid, Penyelesaian Sengketa Komersian Nasional dan Internasional di Luar Pengadilan, Paper, September 1996
} 
analyzed that the dispute settlement proceedings, the Land Office plays an important role in the process of survival of the trial. In this case the strong evidence supporting the strengthening of the District Land Office Purworejo very important in the consideration of the judge to decide either plaintiff or severe side defendant which later in the judge's decision comes the intersection who stated be defendant or in other words convicted.

\subsection{Consideration Justice in Case No. 32 / Pdt.G / 2018 / PN. Pwr about Grant Dispute}

\subsubsection{Judge consideration}

Judges Consideration according to the Act No. 48 of 2009 concerning Judicial Authority Judge considerations are the thoughts or opinions of judges in decisions by looking at the things that can alleviate or incriminate the perpetrator. Each judge is obliged to submit for consideration or written opinion on case being examined and become an integral part of the decision. Like in the Theory of Scientific Approach the starting point of this theory is the idea that the process of sentences should be done with caution especially relation to the previous decision in order to ensure the consistency of the judge's decision.

This scientific approach is a kind of warning that in deciding a case, a judge should not be solely on the basis of an institution, but must be equipped with legal knowledge and scientific insights in facing a case the judge must decided. So in deciding a case before the judge offers peace efforts of the parties or mediation.

Consideration of Purworejo District Court in its Decision 32 / Pdt.G / 2018 / PN.Pwr against the elements accused by the plaintiff which in the initial step of judges offers peace efforts or provide input to the parties that the best decision is the decision of peace and judges gave the following basic considerations: Considering that the judges have sought peace through mediation between the parties as stipulated in the Indonesian Supreme Court No. 1 of 2016 on Mediation Procedure of the Court. ${ }^{7}$

\subsubsection{Mediation According to the Supreme Court Regulation No. 1 of 2016.}

The judges basically before bringing a case the parties to court have sought peace among the parties through the mediation as set forth in Supreme Court Regulation No. 1 of 2016 on mediation procedure in the Court by appointing Setyorini Wulandari, SH, $\mathrm{MH}$, Judge at the District Court Purworejo as mediator. About procedure of mediation in court, which is an obligation that must be taken by the parties in the court to conduct peace mediation efforts.

The judge found in the district court that has been set by the chairman of the court and then ditempatkaan in the list of mediators and judges examination to exclude from the principal case. Which further bias only court staff are already certified or the third is a mediator certified mediator. And mediation time was 30 days plus 30 working days if they necessitate. If at the first mediation meeting point is not reached between the

\footnotetext{
${ }^{7}$ Chairman of the Supreme Court, PERMA RI. No. 1 of 2008 on Mediation Procedure of the Court.
} 
plaintiff and the defendant about what is required and kesanggupanya and otherwise failed mediation and then enter in the principal case.

So in terms of consideration Purworejo District Court in its Decision 32 / Pdt.G / 2018 / PN.Pwr against the elements accused by the plaintiffs or parties both defendant namely:

- Considering that for strengthen their arguments the plaintiff has filed written evidence marked 15 P.1 to p.15 and three witnesses namely Samingan, Eddy Untoro and Witness Edi Sigit Rendarwoko.

- Considering that in order to support their arguments on replict of defendant and co-defendant I have filed written evidence marked 8 T.1 until T.8 and two witnesses namely Parno and Mingan.

- Whereas since plaintiffs' argument number 1 which is supported by evidence P.1, P.2, P.3 justified and recognized by defendant as the arguments of the answer at point 2 , the recognition is a testament to the perfect unnecessary to prove again that the assembly judge will not consider again, while particularly regarding the arguments are considered denied by the judges.

- Considering that the legal flaw in the process of issuance of Certificate of Property Rights 621 (evidence T.2) hence it is also proof that the strength of the certificate as authentic act which lag raise objections to the certificate has passed five years has been their paralyzed with their opponents evidence based proof P.5, P.6, P.7 with witness testimony Sigit Hendarwoko Edi. Thus therefore 621 certificate (proof T.2) has proven the certificate issuance process disability law then against 621 property certificates (proof T.2) otherwise have no binding force, so as to topetition 4 Plaintiffs legal grounds for accepted.

- Considering that every person who feel that their rights are violated, it can perform a civil action on the basis of tort as provided for in Article 1365 of the Civil Code, which reads :

- "Each unlawful act and bring harm to others, obligate people which impact loss was due to replace the loss of mistaken".

- Considering, that against all 7 Plaintiffs' petition Defendant want to pay for material compensation of Rp. 429300000 (four hundred and twenty nine million three hundred thousand rupiah) to the Plaintiff and should paid in cash after this decision has permanent legal force.

So the authors analyzed the consideration of the judge that in this case carry out the inspection on November 5, 2018 the disputed results of the examination as stated in the minutes of the hearing on 5 November 2018,

- Local examination

Site inspection is the means provided by the legislation to the judge commissioners or judges to clarify a fact or object that is being disputed. Local examination often abbreviated PS. In addition to gerechtelijke plaatsopneming, Dutch language, the inspection also known plaatselijke opneming en Onderzoek. Onderzoek term synonymous with the investigation (British), which means inquiry or investigation. The term is not exactly fallen into disuse after the birth of the Criminal Procedure Code. The term investigations lead to criminal matters. The provisions of the 
inspection can be found in the HIR / RBg. Formerly HIR / RBg is used as the criminal and civil procedural law as well. But now HIR / RBg only be used as civil law.

The legal basis (rechtsgrond) local examination: - Article 153 HIR / Article 180 RBg / Article 211- Article 214 - SEMA No. 7 of 2001.

Site inspection is an examination or a trial conducted by the judges / civil judges in the object that is being disputed is located. The judge / judges are coming to where the object (usually ground) to see firsthand the state of the object or the disputed land. ${ }^{8}$

- verification

Then in accordance with the provisions of Article 136 HIR and the Supreme Court Decision 935 / Sip / 1985 against the Exception must be examined and decided upon together with the principal case ${ }^{9}$, So the judges before deciding his case should be examined and decided upon jointly, assembly check includes both the defendant's claim and the claimant as well as examining the evidence as SHM land area $621 \mathrm{~m} 22636$ different objects with the land parcels of land rights of Yasan C 1752. After that the judges also consider to evidence that will be examined and considered between evidence that has been presented by the parties, both plaintiff and defendant. So there is a correlation with the principle of legal certainty because the judge had to go through a lot of consideration and there is good evidence supporting the plaintiff or defendant.

Legal certainty not only in the form of articles of the law but also their consistency in the verdict the judge's decision with each other for similar cases that have been decided. Legal certainty is the certainty of the rule of law, not the certainty of action in accordance with the rule of law. Normative legal certainty is when a rule is made and enacted exactly as it can provide a clear and logical arrangement.

Obviously in a sense does not cause doubt or multi interpretation and logical is the law is as a system of norms the other norms that no clash or conflict which impact norm or blurring and empty norm. So, the judge in state court in Purworejo do duties or compulsory considering guided by normative to the rule of law with regard to any measures to be taken for later stated in the verdict. The rule of law or the verdict would provide certainty to the parties, that decision had been there before the parties is evidence or the end of the dispute process in case of Grant Disputes happen. So the verdict of the judges can be used as guidelines by the plaintiff or defendant.

\section{Closing}

\subsection{Conclution}

- Purworejo District Land Office has an important role in efforts to resolve the Grant Disputes in case Number 32 / Pdt.G / 2018 / PN.Pwr which provide an important role in the continuity of the process of the trial. In this regard the strengthening of

\footnotetext{
${ }^{8}$ Yahya Harahap, 2005, Hukum Acara Perdata, Sinar Grafika, p.21

${ }^{9}$ Ali Budiarto, 2003, Kompilasi Peraturan Hukum Acara Perdata, Varia Peradilan, Ikatan Hakim Indonesia, p 34
} 
proofCopy the appropriate native land book 621 of the National Land Agency, given the evidence of TTII-1; Copy the original suit, Grant Deed No. 44 / PPAT / Gebang / 1990, marked as evidence TTII-2; of the District Land Office Purworejo very important in the consideration of the judge to decide either plaintiff or severe side defendant which natinya in the judge's decision comes the intersection who berstatuskan defendant or in other words convicted.

- Judge considering in the case Number 32 / Pdt.G / 2018 / PN.Pwr on the dispute that is the first judge's grant offer mediation process in accordance with the Supreme Court of Indonesia Regulation Number 1 of 2016 about the mediation process, because the best decision is a decision for peace. However, if the process does not come to fruition in a predetermined amount of time entered in the proceedings that began on the inspection process, the verification of the parties to the stage reading of the verdict.

\subsection{Suggestion}

- For Purworejo District Land Office in the recording process or transfer Persil 84, C 2194 II 0,067 ha area to be more careful, because in this case the object quo is fraudulent or intentional act of defendant.

- In the examination of the dispute to the future location of the judges should always conduct a review of the location as to strengthen the existing evidence from Purworejo district Land Office or of the applicant party or defendant which the assembly will be considering evidence that already exists.

\section{Bibliography}

\section{Book:}

[1] Rachmadi Usman, 2009, Hukum Agraria , Jakarta : Sinar Grafika

[2] Ronny Hanitijo Soemitro, 2003, Metodologi Penelitian Hukum, Ghalia Indonesia, Semarang.

[3] Bambang Waluyo, 1996, Metode Penelitian Hukum, Jakarta : Sinar Grafika.

[4] H. Zainuddin Ali, 2011, Metode Penelitian Hukum, Jakarta : Sinar Grafika.

[5] Ronny Hanitijo Soemitro, 2003, Metodologi Penelitian Hukum, Ghalia Indonesia, Semarang.

[6] Lexy J. Moleong, 2007, Metodologi Penelitian Kualitatif. Bandung: Remaja Rosda Karya.

[7] Bambang Sugugono, 2003, Metode Penelitian Hukum, PT Raja Grafindo Persada, Jakarta

[8] Priatna Abdurasid, Penyelesaian Sengketa Komersian Nasional dan Internasional di Luar Pengadilan, Makalah, September 1996

[9] Ketua Mahkamah Agung RI, PERMA RI. No. 1 Tahun 2008 tentang Prosedur Mediasi di Pengadilan.

[10] Yahya Harahap, 2005, Hukum Acara Perdata, Sinar Grafika.

[11] Ali Budiarto, 2003, Kompilasi Peraturan Hukum Acara Perdata, Varia Peradilan, Ikatan Hakim Indonesia 


\section{Constitution :}

[1] Act No. 5 of 1960 on Basic Regulation of Agrarian (BAL)

[2] Regulation of the National Land Agency of the Republic of Indonesia No. 4 of 2009

[3] Chairman of the Supreme Court, PERMA RI. No. 1 of 2008 on Mediation Procedure of the Court. 